\title{
Waltzing on the Vienna Consensus on Drug Control? Tensions in the International System for the Control of Drugs
}

\author{
by Neil Boister*
}

\begin{abstract}
This article examines the tensions within the international drug control system which are putting the until now consensual position in regard to the prohibition on drugs supply and use for anything other than medical and scientific use - the Vienna Consensus - under strain. The article examines a number of areas where policy stress is leading to controversy about potential violation of international drug control treaty obligations by States parties. Drawing a comparison with earlier periods of stress when drug control fell under the League of Nations, it suggests that what appears to be occurring is a shift in the Vienna consensus, and that the drug conventions are sufficiently flexible to permit resulting shifts in practice, although reform would be preferable.
\end{abstract}

\section{INTRODUCTION}

The current international drug control system was built under the auspices of the United Nations, and is centred institutionally in Vienna. Vienna is the location for the annual convening of the UN's Commission on Narcotic Drugs (CND), the UN's principal specialist policy organ on drug control, and for the sessions of the International Narcotics Control Board (INCB), the expert technical committee which monitors global drug control. It is also the home of the UN Office on Drugs and Crime (UNODC), which provides administrative facilitation for the system. ${ }^{1}$ At the heart of the system is apparent consensus about drug prohibition except for medical and scientific purposes. Expressed through the provisions of the drug conventions, it is reflected institutionally in the usually consensus based decision making processes within the CND. ${ }^{2}$ This support for a single position on drug control stands in stark contrast to the highly conflictual situation that developed within the League of Nations international drug control fora in the pre-War period. The commodity control agreements ${ }^{3}$ which formed the basis of League control had been under significant stress in the period up to 1941 because of controversy over regulated drug markets in territories in Asia under colonial control producing surpluses that fed into, in particular, demand in the United States. ${ }^{4}$ The League's drug control system foundered

\footnotetext{
* Professor, Faculty of Law, University of Waikato, New Zealand (nboister@Waikato.ac.nz). This work was completed while the author was a visiting scholar in the Faculty of Law at the University of Hamburg, funded by the receipt of a Friedrich Wilhelm Bessel Prize from the Alexander von Humboldt Foundation. My thanks to my host Florian Je $\beta \beta$ berger, the Humboldt Foundation, and to Roger Clark, Jonathan Liberman and Rick Lines and anonymous commentators, who were kind enough to read drafts. Any errors are my own.

${ }^{1}$ See S.K. Chatterjee, Legal Aspects of International Drug Control (The Hague: Nijhoff, 1981) 227.

${ }^{2}$ Rule 57 of the Rules of Functional ECOSOC Commissions which include CND requires the Commission to vote when a member requests, and adoption without a vote where no such request is made. The usual practice is not to ask for a vote in the practice in the CND except in regard to the scheduling of drugs. The Rules are available at $<$ http://www2.ohchr.org/english/bodies/chr/docs/rules.pdf $>$.

${ }^{3}$ Herbert L. May, 'Narcotic Drug Control: Development of Action and the Establishment of Supervision under the United Nations' (1948) 441 International Conciliation 303, 305.

${ }^{4}$ See generally, William O. Walker III, Opium and Foreign Policy: The Anglo American Search for Order in Asia 1912-1954 (Chapel Hill: The University of North Carolina Press, 1991); John
} 
during World War II. The principle of international control was not, however, rejected. Harry Anslinger, long serving US Commissioner of Narcotics (from 1931) and US representative on the League of Nations Opium Advisory Committee and then on the UN's Commission of Narcotic Drugs (CND), believed that under the UN system 'world cooperation [embraced the] entire group of civilized nations' under 'American leadership'. ${ }^{5}$ The League's powers were transferred to the United Nations in the Lake Success Protocol in 1946. ${ }^{6}$ The 1961 Single Convention on Narcotic Drugs, ${ }^{7}$ its 1972 Protocol Amending the Single Convention on Narcotic Drugs, ${ }^{8}$ and the 1971 Convention on Psychotropic Substances ${ }^{9}$ introduced a more tightly girdled structure for global drug supply that limited both supply and use to medical and scientific purposes (although at the time advocates of even stricter drug control within the US administration such as Anslinger thought the 1961 Convention too flexible leading to their resisting its adoption ${ }^{10}$ ). A more fully-developed law enforcement apparatus to suppress organized supply of drugs for illicit purposes was adopted in the 1988 United Nations Convention against Illicit Traffic in Narcotic Drugs and Psychotropic Substances. ${ }^{11}$ These international treaties were the culmination of a 'long game' ${ }^{12}$ for the United States that had begun in 1909 with attempts to stop the opium trade into China at the Shanghai Opium Commission. ${ }^{13}$

During the period of United Nations stewardship of the drug control system considerable efforts have been undertaken both at the international and national levels to institutionalise and implement the promises that States parties have made in these conventions. Remarkably, most States have stayed in step with global drug prohibition. It has been argued that 'soft defection' through measures ameliorating the impact of these laws on users has occurred $^{14}$ but the drug conventions have in fact proved flexible enough in their language to permit such 'defection' to occur within the ambit of the promises made by State parties because the convention are not as prescriptive as more ardent prohibitionists would have liked.

M. Jennings, The Opium Empire: Japanese Imperialism and Drug Trafficking in Asia, 18951945 (Westport, Connecticut and London: Praeger, 1997); William B. McAllister, Drug Diplomacy in the Twentieth Century: An International History (London: Routledge, 2000).

${ }^{5}$ Pennsylvania State University, Special Collections, Historical Collections and Labor Archive, Harry Anslinger Papers, Box 4, File 2, Notes for the Opium Question, under title 'International', p2.

${ }^{6}$ The Lake Success Protocol amending the Agreements, Conventions and Protocols on Narcotic Drugs Concluded at the Hague on 23 January 1912, at Geneva on 11 February 1925 and 19 February 1925, and 13 July 1931, at Bangkok on 27 November 1931 and at Geneva on 26 June 1936, signed at Lake Success, New York, 11 December 1946, 12 UNTS 179. In force upon signature for each party in accordance with the provisions of the drug control treaties. See Chatterjee (n 1), 326.

${ }^{7}$ New York, 30 March 1961, 520 UNTS 151; in force 13 December 1964.

${ }^{8}$ Geneva, 25 March 1972, 976 UNTS 3; in force 8 August 1975.

${ }^{9}$ Vienna, 21 February 1971, 1019 UNTS 175; in force 16 August 1976.

${ }^{10}$ See David Bewley-Taylor, International Drug Control: Consensus Fractured (Cambridge: CUP, 2012), 136 et seq.

${ }^{11}$ Vienna, 20 December 1988, 1582 UNTS 95; in force 11 November 1990.

${ }^{12}$ A term used by Harry Anslinger when he convinced the British and Dutch to give up their opium monopolies in 1943 - Pennsylvania State University, Special Collections, Historical Collections and Labor Archive, Harry Anslinger Papers, Box 5, File 9, Scrapbook.

${ }^{13}$ See Hamilton Wright, ‘The International Opium Commission’ (1909) 3 American Journal of International Law 652.

${ }^{14}$ David Bewley Taylor and Martin Jelsma, 'Regime Change: Re-visiting the 1961 Single Convention on Narcotic Drugs' (2012) 23 International Journal of Drug Policy 72, 73. 
Provisions safeguarding State party discretion in implementation are, for example, common. ${ }^{15}$ Recently, however, more challenging notes of dissonance have begun to be heard from States. Given the existence of these tensions and the upcoming United Nations General Assembly Special Session on drugs in 2016 which provides an official opportunity for some reassessment of the system of international drug control by States, ${ }^{16}$ it is timely to ask whether, and if so why, States have begun 'Waltzing on Vienna'.

There are many areas of policy tension within the evolving global drug control system, but only a few have led to reference to the provisions of the drug conventions and to claims of transgression of the objectives of the system. This piece begins in part 2 by examining a clear signifier of tension in the system: renewed interest in the object and purpose of the system. With a view to a general comment on their systemic and broader impacts, part 3 briefly examines a number of these topical areas of tension within the global illicit drug control system, summarising the policy battles and their effect on the legal rules. The areas examined (in rough chronological in order to give some sense of the historical growth of discord in the system) are State flexibility on personal use, harm reduction, human rights issues, Bolivia's denunciation and re-ratification with reservation in regard to coca leaves, and the introduction of legal use and legal markets for cannabis within certain States. Part 4 then engages in an assessment of the general systemic impact of the system of these tensions.

\section{THE OBJECT AND PURPOSE OF THE INTERNATIONAL DRUG CONTROL SYSTEM}

The objectives of the international drug control system took some time to settle. As noted above, the League period saw a struggle between States like Britain, which sought only official control of supply but without limitation of use, and the United States, which sought limitation of supply only for these exclusive uses, a struggle won by the United States. Following Vienna Convention ${ }^{17}$ orthodoxies a textual analysis of the current drug conventions reveals that their common objectives are to specifically limit 'the production, manufacture, export, import, distribution of, trade in, use and possession of' the drugs scheduled under the treaties 'to medical and scientific purposes' ${ }^{18}$ and to 'suppress' other illicit activities. ${ }^{19}$ These objectives are entwined; the principle that certain activities are to be exclusively lawful dictates that other activities are not and those are the activities to be suppressed. At the Diplomatic Conference that settled the 1961 Single Convention, the British Representative, Mr. Green, the first speaker at the negotiations, noted

\footnotetext{
${ }^{15}$ See, for example art 36(1)(a) and art 36(4) of the 1961 Convention, art 22(1)(a) of the 1971 Convention and art 3(2) and 3(11) of the 1988 Convention.

${ }^{16}$ See UNGASS 2016 - Special Session of the United Nations General Assembly on the World Drug Problem, at <www.unodc.org/ungass2016/en/about.html $\geq$. For a background to the policy debates at the two previous UNGASS meetings in 1998 and 1998 see Martin Jelsma, UNGASS 2016: Prospects for Treaty Reform and UN System-Wide Coherence on Drug Policy (Washington: Brookings, 2016), 5 et seq.

${ }^{17}$ Art 31 and 32 of the Vienna Convention on the Law of Treaties, 19691155 U.N.T.S. 331, 8 I.L.M. 679, entered into force Jan. 27, 1980.

18 Preambular para 8 and art 4(c), 1961 Convention; preambular para 5 and art 5(2) 1972 Convention.

${ }^{19}$ Preambular paras 5, 10 and 13, and art 2 of the 1988 Convention.
} 
that narcotics control had two aspects: The limitation of production to legitimate purposes and the prevention of the illicit traffic. The object was to eliminate abuses without hindering the use of narcotics for therapeutic purposes or impeding scientific progress. ${ }^{20}$

The preamble of the 1961 Single Convention reminds us that it is designed to provide for 'continuous international co-operation and control for the achievement of such aims and objectives' ${ }^{21}$ The system thus requires sustained adherence to these objectives of limitation and elimination. While the drug conventions do permit discretion to States parties in certain areas such as treatment of users they do no permit the same degree of latitude in regard to control of the supply of drugs.

Until recently most States parties have concentrated upon suppression as a technical problem and there has been little interest in exploring the drug control system's ultimate purposes. Recent pressure for change exerted by civil society has refocused attention on the system's purpose. Lines, drawing on the preambles of the drug conventions, notes that this purpose is to attain its objectives for the benefit of the 'health and welfare of mankind', ${ }^{22}$ and this view is shared by the UN General Assembly in $2014 .{ }^{23}$ Whether the objectives of limitation to medical and scientific purpose and suppression of the illicit activities have or ever will achieve the health and welfare of mankind is, however, increasingly disputed. ${ }^{24}$ Critics argue that the system operates on the undemonstrated assumption that suppressing supply and demand will achieve positive health and welfare outcomes and that even on its own terms it has failed to suppress these activities. ${ }^{25}$ The following areas of tension in the international drug control system serve as focal points for this kind of criticism.

\section{AREAS OF TENSION IN THE INTERNATIONAL DRUG CONTROL SYSTEM}

\subsection{Flexibility on Personal Use}

Signs of a more flexible position being taken by States in regard to the objective of elimination of abuse of proscribed drugs first appeared in the modulation of their approaches to personal use offences. The UN Drug Conventions do not oblige States parties to criminalise use per se; instead possession for personal use functions as a proxy offence to achieve this purpose. Article 36(1) of the 1961 Single Convention had limited the obligation on States parties to establish the possession of drugs for personal use as a 'punishable offence'. The 1961 Convention and the 1971 Convention were silent on the purposes of possession which allowed States parties to develop different positions on possession. The flexible interpretation adopted by some States

${ }^{20}$ United Nations Conference for the Adoption of a Single Convention on Narcotic Drugs, Official Records, Volume I (New York, 1964) UN Doc. E/CONF.34/24; UN Publication Sales No. 63.XI.4., p4.

${ }^{21}$ Preambular para 8.

${ }^{22}$ Preambular para 1 of the 1961, 1971 and 1988 Conventions. See Richard M. Lines, The Fifth Stage of International Drug Control: International law, Dynamic Interpretation and Human rights (Unpublished $\mathrm{PhD}$ Thesis, Middlesex University, 2014), 176-181 [permission]; see also Damon Barrett and Manfred Nowak, 'The United Nations and Drug Policy: Towards a Human Rights Based Approach’ in Aristotle Constantinides and Nikos Zaikos (eds), The Diversity of International Law: Essays in Honour of Professor Kallipi K. Koufa (Brill/Martinus Nijhoff), 449, 461.

${ }^{23}$ GA Resolution 69/201, 18 December 2014, preambular para 6.

${ }^{24}$ See generally, Bewley-Taylor (n 10), 11.

${ }^{25}$ Barrett and Nowak (n 22), 461. 
that the obligation was limited to possession for supply purposes was reflected in the UN's Commentary on the Single Convention on Narcotic Drugs. ${ }^{26}$ Pressure in the negotiation of the 1988 Convention on supply-side states to take responsibility for interdicting drug flows led Mexico to attempt to re-balance the burden of obligations in the Convention onto demand-side States by establishing an unambiguous obligation to establish possession for personal consumption as an offence. ${ }^{27}$ Article 3(2) requires States parties

to adopt such measures as may be necessary to establish as a criminal offence under its domestic law, when committed intentionally, the possession, purchase or cultivation of narcotic drugs and psychotropic substances for personal consumption, contrary to the provisions of the 1961 Convention, the 1961 Convention as amended or the 1971 Convention.

However, even here, as a result of the lack of consensus about using criminalization the text contains a safeguard clause subjecting the obligation to the 'constitutional principles and the basic principles of [the party's] legal system'. If these options for not criminalising are not available, the express terms 'to establish as a criminal offence' present a clear obligation. The UN's Commentary on the 1988 Convention, however, recognises that the provisions for treatment and rehabilitation in article $3(4)(d)$ as an alternative to punishment affords States parties some latitude in regard to how to execute the obligation in article 3(2). ${ }^{28}$

In the 1960s and 1970s states within the United States were the first to begin to reduce the penalties for cannabis use, then began stopping prosecuting cannabis personal use offences as a matter of policy, and finally decriminalised entirely. ${ }^{29}$ In Europe, the Netherlands decriminalised personal use in $1976 .{ }^{30}$ In the late 1980s states in Australia began to decriminalise by applying administrative penalties. ${ }^{31}$ The causes of relaxation varied from the negative human rights implications of criminalisation to more prudential use of public and in particular law enforcement resources.

These modulations have not usually constituted direct challenges to the objectives of the drug conventions. Spain (1992) $)^{32}$ and Italy (1990), ${ }^{33}$ for example, adopted a system of administrative penalties for possession of all drugs which arguably conform to the conventions.

${ }^{26}$ Commentary on the Single Convention on Narcotic Drugs, 1961, (New York: UN, 1973), UN Publication Sales No. E.73.XI.1., 112.

27 See United Nations Conference for the Adoption of a Convention against Illicit Traffic in Narcotic Drugs and Psychotropic Substances, Official Records, Volume II (New York, 1991) UN Doc. E/CONF.82/16/Add.1, 53.

${ }^{28}$ See Commentary on the United Nations Convention against Illicit Traffic in Narcotic Drugs and Psychotropic Substances, 1988 (New York, 1998) UN Doc. E/CN.7/590; UN Publication Sales No.E.98.XI.5., 81, par 3.94.

${ }^{29}$ Oregon was the first state to change its law, with the Oregon Decriminalization Bill of 1973. For a review of cannabis prohibition in the US see Richard J. Bonnie and Charles $\mathrm{H}$. Whitebread, II, 'The Forbidden Fruit and the Tree of Knowledge: An Inquiry into the American Legal History of Marijuana Prohibition’ (1970) 56 Virginia Law Review 971-1169.

${ }^{30}$ Opiumwet, Staatsblad 1976: 424. See Sebastian Scheerer, 'The New Dutch and German Drug Laws: Social and Political Conditions for Criminalization and Decriminalization’ (1978) 12 Law and Society Review 585, 587.

${ }^{31}$ In 1987 South Australia introduced a Cannabis expiation Notice (CEN) policy. See Wayne Hall, 'The Recent Australian Debate about Prohibition of Cannabis Use' (1997) 92 Addiction 1109.

32 Organic Law 1/1992 of 21 February 1992.

${ }^{33}$ Presidential Decree 309 of 9 October 1990. 
Portugal when explaining its partial abandonment of criminalisation of personal use offences in $1999^{34}$ maintained it adhered to the 1988 Convention's obligation to establish a domestic law prohibition on these activities. ${ }^{35}$ The International Narcotics Control Board (INCB), which took upon itself the task of maintaining the integrity of the system, was quick to 'remind' States of their obligation under article 3(2) of the 1988 Convention. ${ }^{36}$ State practice like Portugal's, however, indicated increasing use of the inbuilt capacity for flexible interpretation of article $3(2)$ 's obligation 'to establish as a criminal offence', if only in limited cases. In 2004 the INCB conceded that 'the practice of exempting small quantities of drugs from criminal prosecution is consistent with the international drug control treaties', but continued to emphasise that the objectives of the conventions were to limit abuse. ${ }^{37}$ In 2009, utilising the safeguard clause to article 3(2), Mexico passed a law providing that possession of small amounts of heroin, opium, cannabis and cocaine would no longer lead to criminal prosecution. ${ }^{38}$ The INCB in 2009 in its Annual Report reminded Mexico of its article 3(2) obligations, ${ }^{39}$ but Mexico has not changed its practice. The aforementioned examples illustrate legislative/executive use of the safeguard clause but the domestic courts have also used this clause. In 2009 the Argentine Supreme Court declared criminalisation of possession for personal consumption in private places a constitutional breach because it interferes with the right to personal autonomy. ${ }^{40}$

Faced with this wave of reforms in regard to personal use in 2009 the INCB responded generally that it was concerned about political support for the movement to decriminalize possession among high profile politicians and noted that the movement posed a 'threat to the coherence and effectiveness' of the system, sent the 'wrong message to the general public', and unless 'resolutely countered' would undermine drug control. ${ }^{41}$

\subsection{Harm Reduction}

Harm reduction measures such as drug maintenance and substitution programmes, needle and syringe exchanges, drug consumption rooms, and so forth, present another challenge to the system. ${ }^{42}$ While they are designed to reduce attendant harm of use such as infection, they have been characterised by antagonists inter alia as aiding and abetting in the abuse of drugs. ${ }^{43}$ Their

\footnotetext{
${ }^{34}$ Law 30 of 2000. Possession of drugs for personal consumption, in amounts higher than the ones needed for 10 daily doses, remained a criminal offence.

${ }^{35}$ See Caitlin Elizabeth Hughes and Alex Stevens, 'What can We Learn for the Portuguese Decriminalization of Drugs?' (2010) 50 British Journal of Criminology 999, 1002 et seq.

${ }^{36}$ INCB, Report of the International Narcotics Control Board for 2001, UN Doc. E/INCB, 2001/1 (New York: United Nations, 2002), 74, para 509.

${ }^{37}$ INCB, Report of the International Narcotics Control Board for 2004, UN Doc. E/INCB, 2004/1 (New York: United Nations, 2005), 80, para 538.

${ }^{38}$ Decree of 20 August 2009, amending art 478 of the General Health Act.

${ }^{39}$ Report of the International Narcotics Control Board for 2009, UN Doc E/INCB/2009/1, 68, para 408.

${ }^{40}$ Arriola Ruling, Case No A 891 XLVI Supreme Court of Justice, Argentina, 25 August 2009.

${ }^{41}$ INCB, Report of the International Narcotics Control Board for 2009, UN Doc. E/INCB, 2009/1 (New York: United Nations, 2010), 75, para 453.

${ }^{42}$ See generally Bewley-Taylor (n 10), 102 et seq.

43 See Joanne Csete and Jonathan Cohen, 'Human Rights Abuses faced by Injection Drugs Users in the Era of HIV/AIDS', in Kasia Malinowska-Sempruch and Sarah Gallagher (eds), The War on Drugs, HIV/AIDS and Human Rights (New York: International Debate Education Association, 2004), 212, 217.
} 
legality can be defended through reference to the narrow interpretive scope ${ }^{44}$ that flows from the absence of a constraining definition of 'medical and scientific purposes' and provision in the conventions for States parties at their discretion to offer measures of treatment, education, aftercare, rehabilitation, and social integration as alternatives or additions to criminal penalties. ${ }^{45}$ Under the UN Political Declaration on the Guiding Principles of Demand Reduction Control adopted at the 1998 UN General Assembly Special Session on the World Drug Problem, States committed to offer 'the full spectrum of services, including reducing the adverse health and social consequences of drug abuse for the individual and for the society as a whole'. ${ }^{46}$ Yet the UN's drug control organs in Vienna and in particular the CND have been the forum for an ongoing political rather than legal conflict about the use of 'harm reduction', placing them out of step with other UN organisations involved with public health where its use is commonplace. ${ }^{47}$ In 2002 the UNDCP legal section opined that there was sufficient flexibility in the drug conventions to accommodate harm reduction. ${ }^{48}$ Yet the term is not used at all, for example, in the 2014 report of the INCB. ${ }^{49}$

The conflict over the legality of drug injection rooms provides a concrete example of the harm reduction debate. These safe facilities for drug use are provided lawfully in Australia, Canada, Germany, Switzerland, the Netherlands, Luxembourg, Spain and Norway. In spite of recognition by the WHO of 'compelling evidence' that they reduce HIV infections in a cost effective manner, ${ }^{50}$ in 2000 the INCB noted that establishing drug injection rooms 'is contrary to the international drug control treaties ${ }^{51}$ and in 2004 stated 'they are against the central principle embodied in the drug control treaties, namely that the use of drugs should be limited to medical and scientific purposes only. ${ }^{52}$ Proponents argued that these rooms are lawful so long as they did not permit sale, acquisition or passing on of drugs, are genuinely risk reducing, and subject to adequate control. ${ }^{53}$ They noted that the drug conventions are silent on whether these rooms constitute a legitimate practice of social reintegration and rehabilitation, that state practice is unclear, and therefore argued the matter is for States parties. ${ }^{54}$ Finally, they pointed to the protection of fundamental human rights. In 2008 the Supreme Court of British Columbia held in PHS Community Service $v$ Attorney General of Canada ${ }^{55}$ that access to the INSITE injecting facility in Vancouver was guaranteed by the right to life under section 7 of the

${ }^{44}$ Report of the Special Rapporteur on the Right of Everyone to the Enjoyment of the Highest Attainable Standard of Physical and Mental Health, UN Doc A/65/255, 6 August 2010, 16; Dave Bewley-Taylor and Martin Jelsma, The UN Drug control Conventions: The Limits of Latitude, TNI/IDPC Series on Legislative Reform of Drug Policies, no.18, March 2012, 9.

${ }^{45}$ Art 36(1)(b) of the 1961 Convention, art 22(1)(b) of the 1971 Convention and art 3(4)(d) of the 1988 Convention.

${ }^{46}$ UN Doc. A/Res/S20/4, 10 June 1998.

${ }^{47}$ Bewley-Taylor (n 10), 132-4.

${ }^{48}$ Decision 74/10, Flexibility of Treaty Provisions as Regards Harm Reduction Approaches, prepared by UNDCP 's Legal Affairs Section, E/INCB/2002/W.13/SS.5, 30 September 2002, 49 INCB, Report of the International Narcotics Control Board for 2014, UN Doc. E/INCB, 2014/1 (New York: United Nations, 2015).

${ }^{50} \mathrm{WHO}$, Effectiveness of sterile needle and syringe programming in reducing HIV/AIDs among injecting drug users (Geneva, 2004), 28.

${ }^{51}$ INCB, Report of the International Narcotics Control Board for 2001 (n 36), 74, para 510.

52 INCB, Report of the International Narcotics Control Board for 2004 (n 37), 77, para 510.

${ }^{53}$ Dr Körner, Chief Public Prosecutor Frankfurt-am-Main, Report on the Admissibility of Health Care Centres for Hygienic and Stress-free Consumption by Opiate Addicts, Frankfurt, 1996.

54 The Swiss Institute of International And Comparative Law, AVIS 99-121c, Use of Narcotic

Drugs in Public Injection Rooms under Public International Law, 7 January 2000.

552008 BCSC 661. 
Canadian Charter of Rights and Freedoms and was not overridden by international drug control treaties, a decision upheld on appeal both to the British Columbia Court of Appeal in PHS Community Services $v$ Canada (Attorney General) ${ }^{56}$ and to the Supreme Court in Canada (Attorney General) v PHS Community Services Society. ${ }^{57}$ The INCB responded in 2011 that 'the provisions of internal law cannot be invoked to justify non-compliance with provisions of the international drug control treaties to which a State has become a party'. ${ }^{58}$ However, by 2014 it had ameliorated its position, simply reiterating 'its concern that such facilities could be inconsistent with the provisions of the international drug conventions. ${ }^{59}$ The INCB's position only indicates that it thinks that the system is threatened by harm reduction; it does not speak for all States parties in this regard. There is probably sufficient flexibility within the system to accommodate harm reduction because as it is aimed at amelioration of conditions affecting the health and welfare of users of drugs it does not constitute a direct challenge to the central provisions in the conventions that limit the supply of drugs to medical and scientific purposes.

\subsection{Human Rights Problems}

In addition to harm reduction failures, the human rights failures of the international drug control system are legion. The object of limitation limits access of the vast majority of people to moderate or severe pain relief and more generally restricts access to medicines because of potential diversion to the illicit trade. The object of elimination impacts disproportionately on black people in North America and Europe, drug-crop eradication produces collateral costs to health and the local economy in agricultural drug-producing States, and the use of large-scale violence in operations against drug cartels, police brutality against individual suspects in custody, detention without trial for the purpose of treatment of drug users, and the employment of the death penalty against drug traffickers all have negative human rights impacts. ${ }^{60}$ These shortcomings result from the negligible reference to human rights in the development and administration of the drug conventions, ${ }^{61}$ the result of an absence of consensus at the time on either inclusion of human rights control or a human rights mandate to the drug control bodies. Recent rhetorical commitment to carrying out the commitments in the conventions 'in full conformity' with international human rights instruments is usually finely balanced with reference to state sovereignty and the principle of non-intervention. ${ }^{62}$

It is a matter of concern, however, that the drugs conventions and the drug control institutions have an indirect but influential relationship with human rights abuses; while they do not prescribe them, they do structure the system that employs them at a national level. This relationship of influence is well illustrated by the controversy that surrounds the application of the death penalty to drug supply convictions. As the UN Special Rapporteur on the Right to Health, Anand Grover has recorded, 32 jurisdictions currently apply capital punishment to drug offences, some mandatorily. ${ }^{63}$ Under article 36(1) of the 1961 Single Convention states parties promise that 'serious offences shall be liable to adequate punishment particularly by

\footnotetext{
562010 BCCA 15.

572011 SCC 44.

${ }^{58}$ INCB, Report of the International Narcotics Control Board for 2011 (New York: UN, 2012), 239, para 289.

${ }^{59}$ INCB, Report of the International Narcotics Control Board for 2014 (n 49), 54, para 362.

${ }^{60}$ Barrett and Nowak (n 22), 451-454; Report of the Special Rapporteur on the right of everyone to the enjoyment of the highest attainable standard of physical and mental health, UN Doc A/65/255, 6 August 2010, 10-14.

${ }^{61}$ Barrett and Nowak (n 22), 449.

62 See, for example, operative para 2 of GA resolution 69/201 of 18 December 2014.

${ }^{63}$ Report of the Special Rapporteur on the right of everyone to the enjoyment of the highest attainable standard of physical and mental health, UN Doc A/65/255, 6 August 2010, 8.
} 
imprisonment or deprivation of liberty', although the 1961 Commentary notes that they are entitled to adopt stricter measures including the death penalty. ${ }^{64}$ The 1988 Convention, like most crime suppression conventions neither provides for nor rules out the possible application by a State party of the death penalty. Human rights bodies have, however, criticised executions for drug offences as violations of international law. ${ }^{65}$ The 1988 Convention provisions are not entirely standard free; article 3(4)(a) obliges States Parties to make article 3(1) trafficking offences 'liable to sanctions which take into account the grave nature of these offences, such as imprisonment or other forms of deprivation of liberty, pecuniary sanctions and confiscation.' In 2007, the Indonesian Constitutional Court, in Sianturi and ors $v$ Indonesia, ${ }^{66}$ rejected a constitutional challenge to the imposition of capital punishment on Indonesian and Australian drug traffickers under Indonesia's Narcotics Law No 22 of 1997, by reference to the 1988 Convention. The Court considered that the imposition of death was appropriate because the Indonesian drug trafficking offences implementing the 1988 Convention was a valid exception to the prohibition on interference with the right to life in article 6 of the ICCPR under paragraph (2), which did not prohibit the imposition of the death penalty for the 'most serious' crimes. Rejecting the opinion of the UN Human Rights Committee that drug trafficking offences were not among the 'most serious crimes', ${ }^{67}$ the Court considered there to be no substantial difference between them and 'most serious crimes' like genocide because they also affected the 'economic, cultural and political foundations of society' and carried 'danger of incalculable gravity' ${ }^{68}$ There is little analogous content between core international crimes involving proof of intentional killing and injury, and drug supply offences resting on a presumption of intent to traffic based on volume of the drug carried. Drug supply covers a wide range of conduct from the trivial to the serious, something recognised by the Convention itself through the application of aggravating factors that are by definition not present in every case. ${ }^{69}$ The Indonesian position continues to cause serious tensions with States whose nationals are executed for committing this offence. ${ }^{70}$ The UNODC Executive Director has noted that the weight of opinion is that these offences do not reach the threshold of most serious crimes and has advocated its abolition. ${ }^{71}$ The INCB has also moved on this issue, and now encourages States 'to consider

641961 Commentary (n 26), 449-450.

65 Concluding Observations of the United Nations Human Rights Committee, UN Doc CCPR/CO/84/THA, 8 July 2005, para 14, and Report of the United Nations Human Rights Committee, UN Doc A/50/40, 3 October 1995, para 449.

${ }^{66}$ Constitucional Review, Nos 2, 3/PUU-V/2007; ILDC 1041 (ID 2007), 23 October 2007.

${ }^{67} \mathrm{UN}$ Doc A/HRC/4/20, para 53.

${ }^{68}$ Ibid, para 3.24.

69 Through art 3(5). See Rick Lines, 'The Death Penalty for Drug Offences: What do the international drug control treaties say about 'most serious crimes', University of Essex Human Rights Centre Blogs, 29 May 2015, <http://blogs.essex.ac.uk/hrc/2015/05/29/the-death-penaltyfor-drug-offences-what-do-the-international-drug-control-treaties-say-about-most-seriouscrimes/>.

${ }^{70}$ In April 2015 Australia withdrew its Ambassador because of the execution of two of its nationals for drug trafficking by Indonesia - NBC News, 'Bali Nine: Australia pulls Ambassador from Indonesia after Execution', 29 April 2015, available at $<$ http://www.nbcnews.com/news/world/bali-nine-australia-pulls-ambassador-indonesia-afterexecution-n34996>.

71 UNODC, Drug Control, Crime Prevention and Criminal Justice: A Human Rights Perspective, Note by the Executive Director, UN Doc E/CN.7/2010/CRP.6*_ E/CN.15/2010/CRP.1, 3 March 2010, paras 25 and 26. 
abolishing the death penalty for such offences' ${ }^{72}$ At the 2015 meeting of the UN Commission of Crime Prevention and Criminal Justice the European Union called for the consideration of the abolition of the death penalty for drug offences although the United States noted that the mandate of the INCB did not extend to instructing states on this issue. ${ }^{73}$

The Vienna consensus is considered a hurdle to progress on human rights because it mutes criticism of State practices that violate human rights. ${ }^{74}$ It stands in marked contrast to the strong mutual criticism of State practices by participants in debates within the League's Opium Advisory Committee. ${ }^{75}$ That criticism was, however, directed at failures to enforce limitation, not at violation of rights through limitation or enforcement.

\subsection{Bolivia's Repudiation and Re-ratification with a Reservation of the 1961 Convention} The 1961 Single Convention is in part a response to concerns in the developed world that its problems with the non-medical use of narcotics are fuelled by the traditional cultivation of the plants from which these drugs are derived. ${ }^{76}$ Coca leaf chewing is endemic in Bolivia both as a cultural practice of indigenous people and as a relief for altitude sickness. ${ }^{77}$ There is a conflict between the cultural right of indigenous peoples to enjoy this cultural custom and the obligations under the 1961 Convention. ${ }^{78}$ In terms of article 2(6) coca leaf is subject to all the measures of control in the convention, as well as to specific measures in articles 26 (regulation of cultivation through a national agency and taking possession of crop) and 27 (cultivation for use as a flavouring agent). In terms of article 49(1) a State party could make a temporary reservation in regard to the chewing of coca leaves but in terms of article 49(2)(e) coca leaf chewing had to be abolished within 25 years of the Convention coming into force. It came into force in 1964 and therefore the obligation to abolish coca leaf chewing became absolute in 1989 for those States parties that made the reservation; for other non-reserving State parties coca leaf was subject to control in 1964.

Bolivia, a party since acceding on 23 September 1976, had not made such a reservation and was thus under the obligation to implement control of coca leaf from accession but had never actually implemented this prohibition, maintaining the legality of the practice under its domestic law, ${ }^{79}$ a fact commented on by the INCB. ${ }^{80}$ Bolivia attempted to formalise its position of non-implementation after adopting a new constitution in 2009 that recognised 'the rights of indigenous peoples to their cultural identity, spirituality, practices and customs ${ }^{81}$ and protected coca in its natural state as 'cultural patrimony'. ${ }^{82}$ Citing this conflict with indigenous peoples' rights (by implication with the provisions of the convention) and arguing there was no conflict with the health objects and purposes of the Convention in doing so, Bolivia sought to change

\footnotetext{
${ }^{72}$ Lochan Naidoo, President of the INCB, in INCB, Report of the International Narcotics Control Board for 2014, iii.

${ }^{73}$ UNCCPCJ, Vienna, Thursday 21 May 2015 (authors notes).

${ }^{74}$ Barrett and Nowak (n 22), 496.

${ }^{75}$ OAC, Minutes of the Seventeenth Session: Held at Geneva from October $30^{\text {th }}$ to November $9^{\text {th }}$, 1933, C.661.M.316.1933.XI (Geneva December 1933), 14.

${ }^{76}$ Bewley-Taylor and Jelsma (n 14), 78.

${ }^{77}$ Sven Pfeiffer, 'Rights if Indigenous Peoples and the International Drug Control Regime: The Case of Traditional Coca Leaf Chewing', (2013) 5 Göttingen Journal of International Law 287, 297-8.

${ }^{78}$ Ibid., 295 et seq.

${ }^{79}$ Law 1008 of 19 July 1988 considered coca leaf production and chewing legal; only extraction and supply of cocaine was classed as illegal.

${ }^{80}$ INCB, Report of the International Narcotics Control Board for 2001 (n 36), 57, para 368.

${ }^{81}$ Art 30(II)(2).

${ }^{82}$ Art 384.
} 
its commitments under the Convention by seeking international support to delete article $49 .{ }^{83}$ The Convention provides in article 47 that if a proposed amendment has not been rejected by any party within an 18 month it automatically comes into force; if there are objections ECOSOC must decide if a conference of the parties is necessary to consider the amendment. Twenty one States parties did raise objections to the proposal, while only 18 mainly Latin American States supported it. ${ }^{84}$ The United States, for example, objected as follows:

Through ratification of the Single Convention, member states undertake an obligation to limit the trade and use of drugs exclusively to medical and scientific purposes. Member states also recognise measures against the abuse of narcotic drugs require coordinated and universal action. Schedule I to the Single Convention lists coca leaf as a narcotic drug. In considering the proposed amendment, Member States must remain guided by the principles and objectives of the Single Convention. In accordance with Article 47, paragraph 1(b), of the Single Convention, the mission informs the United Nations that the United States of America, consistent with its general obligations outlined in Article 4 of the Convention, does not accept the proposed amendment. ${ }^{85}$

Ironically it is questionable whether amendment of article 49 would have achieved Bolivia's goal as coca leaf would have remained in Schedule 1 and subject to all the provisions in the Convention.

However, the objections halted further progress and Bolivia did not wait for ECOSOC to decide whether a conference was necessary to clarify matters. It switched tactics and denounced the Convention on 29 June 2011 by notification to the UN Secretary General, with its withdrawal taking effect from 1 January $2012 .{ }^{86}$ It then re-acceded but with the following reservation:

The Plurinational State of Bolivia reserves the rights to allow in its territory: traditional coca leaf chewing; the consumption and use of the coca leaf in its natural state of cultural and medicinal purposes, such as its use in infusions; and also the cultivation, trade and the possession of the coca leaf to the extent necessary for these licit purposes. At the same time, the Plurinational State of Bolivia will continue to take all necessary measures to prevent its abuse and the illicit production of narcotic drugs which may be extracted from the leaf. ${ }^{87}$

Under article 19 of the Vienna Convention on the Law of Treaties, a reservation must not be 'incompatible with the object and purpose of the treaty.' The legal arguments marshalled for acceptance of Bolivia's withdrawal, re-accession and reservation include allowing a State like Bolivia with specific objections to a particular provision to remain in the system of control,

${ }^{83}$ Letter Dated 12 March 2009 From the President of Bolivia Addressed to the Secretary General, UN Doc E/2009/78 enclosure, 15 May 2009, 4.

${ }^{84}$ See Pfeiffer (n 77), 301-2.

${ }^{85}$ Proposal of Amendments by the Plurinational State of Bolivia to art 49, paras 1(c) and 2(e): United States of America, UN Doc E/2011/47, 19 January 2011, 3.

${ }^{86}$ In terms of art 46. See Pfeiffer (n 80), 304. This tactical change was foreshadowed by Helfer's work on treaty exit and reservations - see Laurence R. Helfer, 'Exiting treaties' (2005) 91 Virginia Law Review 579-1648 and 'Not fully committed? Reservations, risk and treaty design' (2006) 31 Yale Journal of International Law 367-382.

${ }^{87}$ UNSG Depository Notification, UN Doc C.N.94.2013.Treaties-VI.18, 10 January 2012. 
while simultaneously conveying the intensity of its objection to the other parties. ${ }^{88}$ The authors of the 1961 Commentary considered a strategy of this kind entirely legal under article 50(3) of the Single Convention, which permits other reservations, stating that 'a party may reserve the right to permit the non-medical uses as provided in article 49, paragraph 1 , of the drugs mentioned therein, but also non-medical use of other drugs, without being subject to time limits provided for in article 49. ${ }^{89}$ However, article 50(3) provides that if one third or more States parties (which put the threshold for Bolivia at 61) objected within one year, the strategy would be defeated. By the end of the period only 15 States parties had objected, a weight of objection insufficient to meet the threshold to block the measure. The objecting States parties as Pfeiffer notes were mainly concerned about 'the legal implications of the reservation for the international drug control regime and for the international law of treaties more generally. ${ }^{, 90}$ Japan objected that the reservation 'seems to be in conflict with the object and purpose of the 1961 Convention to prevent the illicit production, manufacture and trafficking of cocaine'. ${ }^{91}$ Russia worried that ' $[\mathrm{t}$ ]his step also establish a dangerous precedent and might be used by other states in order to establish in their territories more liberal drug control machines that are provided for by the' drug conventions. ${ }^{92}$ Sweden 'had serious concerns regarding the procedure' followed by Bolivia noting that '[s]uch practice would constitute a misuse of the procedure and would undermine the basis of international treaty and the International legal framework for the fight against drugs.' 93 The INCB noted Bolivia' step with regret and continued:

The Board is concerned that, while that course of action is technically permitted under the Convention, it is contrary to the fundamental object and spirit of the Convention. If the international community were to adopt an approach whereby States parties would use the mechanism of denunciation and re-accession with reservations to overcome problems in the implementation of certain treaty provisions, the integrity of the international drug control system would be undermined. ${ }^{94}$

Bolivia's re-accession came into force on the 10 February 2013.

The impact of this process on the general international law of treaties is beyond the scope of this article. However, in the context of international drug control the implication is that the system yielded when pushed hard in novel ways on a single issue. Bolivia had not pursued a process of the interpretation of the conflicting legal obligations but instead forced the drug control obligations to give way not for medical but sociocultural reasons. ${ }^{95}$ The ending of exceptions for the cultivation of specific narcotic producing plants was considered by the 1961 Commentary to be one of the signal achievements of the Single Convention when contrasted

${ }^{88}$ Dave Bewley-Taylor, Tom Blickman and Martin Jelsma, The Rise and Decline of cannabis Prohibition: The History of Cannabis in the UN Drug Control System and Options for Reform, (Amsterdam/Swansea: Transnational Institute/Drug Policy Observatory, March 2014), 62, citing Helfer, 'Not fully Committed? Reservations, Risk and Treaty Design' (2006) 31 Yale Journal of International Law367, 379.

${ }^{89} 1961$ Commentary (n 26), 476.

${ }^{90}$ Pfeiffer (n 77), 305, and sources cited there.

${ }^{91}$ UNSG Depository Notification, UN Doc C.N.84.2013.TREATIES-VI.18, 15 January 2013.

${ }^{92}$ UNSG Depository Notification, UN Doc C.N.88.2013.TREATIES-VI.18, 15 January 2013.

93 UNSG, Depository Notification, UN Doc C.N.732.2012.TREATIES-VI.18, 21 December 2012.

${ }^{94}$ INCB, Report of the International Narcotics Control Board for 2011 (n 58), 37 para 279.

${ }^{95}$ Pfeiffer (n 77), 311, 318. 
with the earlier League treaties. ${ }^{96}$ Unsurprisingly this 'reform by subtraction' has been touted as useful as a tool for wider reform of the system. ${ }^{97}$ From a voluntarist point of view Bolivia's action seem entirely permissible within public international law; its utility as a tool for general reform of the system would require wholesale engagement in similar actions by other States parties, a clumsy and for that reason unlikely prospect. Of more immediate practical import however, is that a measure considered symbolically important in the chain of illicit supply has been rolled back by one State party.

\subsection{The (Re)Introduction of Legal Cannabis Production and Use in Certain States Parties}

The harmfulness of cannabis, coupled with widespread use and enforcement action against that use, has made it something of stalking horse for both the proponents and antagonists of reform of the drug control system. States began to test the system when, as described above, they decriminalised personal use offences. The establishment of what is effectively legal use and supply of cannabis for non-medicinal personal consumption has ratcheted up the challenge to the limitation and elimination objectives of the international drug control system.

The Netherlands has led the way in this regard with its 'coffee shop' system. It claims adherence to article 36(1) of the 1961 Convention and article 3 of the 1988 Convention through its Opium Act, ${ }^{98}$ justifying its inaction in prosecutorial guidelines ${ }^{99}$ that rely on the principle of expediency, which gives the prosecution the discretion not to prosecute if it is in the public interest. The prosecution of offences involving retail sale of up to $5 \mathrm{gm}$ to individual customers and the storage of $500 \mathrm{gm}$ for this purpose has been given the 'lowest judicial priority'. ${ }^{100}$ The Netherlands considers the expediency principle's application in this context to be one of its 'basic legal concepts' protected in the proviso to article 3(2) of the 1988 Convention. The difficulty is the supply of cannabis through the 'back door' into the coffee shops. Legal tolerance of quantities for commercial trading by the shops themselves is not subject to article 3(2)'s proviso but falls under the unqualified obligation under article 3(1). Article 3(6) of the 1988 Convention obliges the States parties to 'endeavour' to ensure that 'discretionary legal powers' are 'exercised to maximize the effectiveness of law enforcement measures'. The Netherlands, however, made a reservation to article 3(6) that it accepted it only to the extent that it accorded with 'Dutch criminal legislation and Dutch policy on criminal matters.' ${ }^{101}$ The INCB has repeatedly condemned this system ${ }^{102}$ but in its latest report was silent, as the Dutch have been joined by other more extravagant dissenters.

Although it had long ceased to penalize possession of small amounts of drugs including cannabis, in 2014 Uruguay legislated to permit the cultivation of up to six cannabis plants as well as the formation and registration of cannabis growing clubs. ${ }^{103}$ But these were exceptions

\footnotetext{
${ }^{96}$ Pfeiffer (n 77), 310 citing the 1961 Commentary (n 26), 110, para 9.

${ }^{97}$ See Robin Room, 'Reform by Subtraction: The Path of Denunciation of International Drug Treaties and Reaccession with Reservations', (2012) 23 International Journal of Drug Policy 401-406.

${ }^{98}$ Opium Wet, 1928.

${ }^{99}$ Office of the Public Prosecutor Guideline, 1996.

${ }^{100}$ Bewley-Taylor and Jelsma (n 44), 14.

${ }^{101}$ Reservation made on acceptance, 8 September 1993 - see UN Treaty Collection, Status of the United Nations Convention against Illicit Traffic in Narcotic Drugs and Psychotropic Substances, available

at

$<$ https://treaties.un.org/pages/viewdetails.aspx?src=treaty\&mtdsg_no=vi-

19\&chapter=6\&lang=en\#EndDec. $>$ last visited 29 April 2015.

102 See for example, Report of the International Narcotics Control Board for 2013, (New York:

UN, 2014), 8, para 54.

103 Through application of Law 19.172 of 2013.
} 
to a step which echoes the State controlled monopolies of the League era: Uruguay institutionalised State control of the chain of supply of the drug through the Institute for Regulation and Control of Cannabis, permitting individuals of 18 years and older to buy up to 40 grams of cannabis from this state monopoly per month. Uruguay acknowledges that there its position is contentious and acknowledges that the drug control conventions may require revision and modernisation, but defends its position by referring to human rights protections and by claiming that its policies accord with the original purposes of the drug control treaties, protection of the health and welfare of mankind. ${ }^{104}$ State controlled sale is yet to take place, but private growing has gone ahead.

Perhaps the most interesting defection, or more kindly, realignment of interests, has occurred in the United States, as it comes to terms with the heavy load that policing and punishing trivial drug offences has placed on its criminal justice infrastructure. When Alaska on grounds of protection of privacy decriminalized possession of four ounces of cannabis in state law through decisions of its courts, ${ }^{105}$ a tension emerged between legality at the state level and illegality at federal level. This tension ratcheted up when beginning with California in 1996, a number of US states introduced limited exemptions for the supply of cannabis for medical purposes. ${ }^{106}$ The US federal authorities had initially continued to prosecute violations by medical cannabis growers of the Controlled Substances Act (CSA) but announced in 2009 that it was adopting a 'Non Enforcement Policy' to the effect it would stop enforcing the federal laws against individuals that comply with state medical marijuana laws. ${ }^{107}$ In 2010 the INCB noted that it was 'deeply concerned about [the] "medical" cannabis schemes' that had been introduced in a number of US states and complained that the " control measures applied in those states to the cultivation of cannabis plants and the production, distribution and use of cannabis fall short of the control requirements of the 1961 Convention' ${ }^{108}$ Its complaint was directed at non-compliance with article 28 of the 1961 Convention, which requires the establishment of a national cannabis agency to which all growers must deliver their crops, if a State party is going to permit the cultivation of cannabis. However, the INCB also felt that the medical utility of cannabis was unproven (a technical classification which the INCB itself is not mandated to make). The INCB applauded the United States Government for stating that it was opposed to the legalization of cannabis and would continue to enforce federal law against cannabis cultivation and supply, which the INCB took as 'confirming the Board's position that federal law supersedes state law with regard to the obligations contained in the international drug control conventions.' ${ }^{109}$

The INCB was not, however, able to prevent the unfolding of a more significant challenge to the international drug control system originating within the United States. Beginning in 2011, state laws have been enacted permitting state regulation and taxation of the

\footnotetext{
${ }^{104}$ Bewley-Taylor, Blickman and Jelsma (n 88), 59.

105 Ravin v. State, 537 P.2d 494 (Alaska 1975); Noy v. State 83 P.3d 538, 544-45 (Alaska Ct. App. 2003). See Jason Brandeis, 'The Continuing Vitality of Ravin v State: Alaskans still have a Constitutional Right to Possess Marijuana in their Homes’ (2012) 29 Alaska Law Review 175. 106 Proposition 215, which took legislative form as the Compassionate Use Act 1996. See generally Bewley-Taylor and Jelsma (n 44), 13.

107 Title 21 USC, Chapter 13. In Gonzales v. Raich, 545 U.S. 1 (2005) the US Supreme Court upheld the authority of US Federal officials to enforce Federal law that conflicts with state law. On the policy change see Robert A. Mikos, "A Critical Appraisal of the Department of Justice's New Approach to Medical Marijuana,” (2011) 22 Stanford Law and Policy Review 633.

${ }^{108}$ Report of the International Narcotics Control Board for 2010, (New York: UN, 2011), 63, para 395.

${ }^{109}$ Report of the International Narcotics Control Board for 2010 (n 108), 63, para 394.
} 
cannabis market initially in Colorado ${ }^{110}$ and Washington ${ }^{111}$ (although they have since been joined by others). The US federal authorities responded with a 2013 Memorandum from the Justice Department, which reaffirmed that cannabis was a dangerous drug and illegal supply a serious crime. ${ }^{112}$ It set enforcement priorities as prevention of sale to minors, the generation of revenue by enterprises, gangs and cartels, diversion to states where it remains illegal, preventing authorised activities from being used as a cover for trafficking in other illegal drugs or illegal activities, violence and the use of firearms in the production of cannabis, drugged driving and other adverse public health consequences, growing on public lands, and growing on federal property. ${ }^{113}$ Noting that it had because of resource limitations usually left enforcement activities that did not fall within these priorities to local and state authorities, its expectations are that these authorities will provide 'strong regulatory and enforcement systems that will address the threat that those state laws pose to public safety, public health and other law enforcement interests. ${ }^{114}$ It will only step in and challenge these state laws if state regulation is ineffective and federal enforcement priorities are threatened. ${ }^{115}$ It clarifies that large scale or for-profit motive of a cannabis operation can no longer by themselves serve as a proxy for the exercise of prosecutorial discretion. Importantly, the memorandum is subject to the proviso that it serves 'solely as a guide to the exercise of investigative and prosecutorial discretion' and 'does not alter the Department's authority to enforce federal law, including federal laws relating to marijuana, regardless of state law'. ${ }^{116}$ The policy does not explicitly approve the creation of cannabis markets within states; it makes it clear that the operation of these markets where they contravene its prosecution priorities will be a Federal priority, but where they do not they will not be a priority. ${ }^{117}$ If the reforms work, however, the implication is that cannabis supply will be left unprosecuted in a number of US states, which it has been argued places the United States in contravention of its treaty obligations. ${ }^{118}$ The Memorandum itself does not address the United States' obligations under the drug conventions. However, its formal position is that it is not violating these conventions because cultivation, trade and possession of cannabis remain criminal offences under Federal drug law in the form of the CSA. ${ }^{119}$ A further leg to this argument appears to be that it believes the treaty provisions permit a 'substantial discretion' regarding where to allocate its law enforcement resources and recognise the limitations placed

${ }^{110}$ Amendment A-64 of 2011, enacted as art 18 section 16 of the Constitution of Colorado.

111 Initiative I-502 (2012).

112 Memorandum for all United States Attorneys. From James M. Cole, Deputy Attorney General. Subject: Guidance Regarding Marijuana Enforcement. August 29, 2013, available on the US Department of Justice Website available at <http://www.justice.gov/iso/opa/resources/3052013829132756857467.pdf.>.

113 Ibid, $1-2$.

${ }^{114}$ Ibid, 2.

115 Ibid, 3.

116 Ibid, 4.

117 See Wells Bennet and John Walsh, Marijuana Legalization is an Opportunity to Modernize International Drug Treaties, Brookings, Washington Office for Latin America, October 2014, 7.

118 Ibid, 8.

11921 U.S.C. §§ 841, 844, 18 U.S.C. § 3607. See Bennet and Walsh (n 117), 2 et seq citing James Cole, Assistant Attorney General, Response to Questions for the Record, Conflicts Between State and Federal Marijuana Laws, Hearing Before the United States Senate Committee on the Judiciary at 4 (June 18, 2014). 
on compliance by a State party's constitution. ${ }^{120}$ The INCB has responded negatively, pointing out that the 1961 Convention limited cannabis to medical and scientific purposes, that the legislation of cannabis in the two states in question 'was not in conformity with the international drug control treaties' and urged 'the Government of the United States to continue to ensure the full implementation of the international drug control treaties on its entire territory., ${ }^{121}$

Does an executive decision not to enforce the law against particular activities (cultivation and supply in its various forms) of a particular drug (cannabis) in a particular place (Washington, Colorado) contravene a party's (the United States) international obligations? Clearly taking action against all contraventions of all drug laws is not required. While confusing as a matter of constitutional law, ${ }^{122}$ the United States position does not appear to be legally tenable as a matter of international law. McNair, writing in 1961 noted the general principle:

The division of powers in Federal States between the Federal Government and the Governments of the States or Provinces give rise to special problems. Normally the treaty-making capacity resides in the Federal government, while the legislative power is divided between the Federal government and the Government of the States and Provinces. The principle is clear that if the Federal Government concludes a valid treaty it is responsible for seeing that it is performed. ${ }^{123}$

A federal state cannot justify its failure to perform a treaty obligation because of any special features of its constitutional system unless otherwise provided in the treaty itself. ${ }^{124}$ The question is whether the drug conventions provide for an exception to the general rule. ${ }^{125}$

A candidate is provision for prosecutorial discretion in the conventions. The right to exercise prosecutorial discretion in regard to that criminalisation is recognised in article 36(4) of the 1961 Single Convention (substantially repeated in article 3(11) of the 1988 Convention), which provides that '[n]othing contained in this article shall affect that principle that the offences to which it refers shall be defined, prosecuted and punished in conformity with the domestic law of a Party.' This provision, a savings provision of a kind commonly inserted in penal law treaties, indicates among other things that the execution of enforcement is a matter for the Parties. ${ }^{126}$ It is a copy of article 15 of the 1936 Convention for the Suppression of the

${ }^{120}$ An argument put to the INCB in 2013 by William Brownfield, the Assistant Secretary of State for International Narcotics and Law Enforcement Affairs, see Bennet and Walsh (n 117), 8.

${ }^{121}$ Report of the International Narcotics Control Board for 2013 (n 102), 49, para 375 and 96, para 713.

122 Bewley-Taylor, Blickman and Jelsma (n 88), 54. The Federal Government cannot command the States to change their laws - New York v. United States, 505 U.S. 114, 162 (1992) and Printz v. United States, 521 U.S. 898, 912 (1997), but can pre-empt these laws under art VI of the Constitution.

${ }^{123}$ A. McNair, The Law of Treaties (Oxford: OUP/Clarendon Press, 1961), 79, fn 1.

124 Harvard Research - Research in the International Law of Treaties, Supplement to 29 American Journal of International Law, October 1935, art 23; LaGrand (Germany v. United States) [2001] ICJ Rep 466, para 111.

${ }^{125}$ While there is no specific reference in art 27 to the possibility that a treaty may expressly justify reference to internal laws as a reason for not meeting an obligation, art 23(a) of the Harvard Draft did admit of this possibility and there is nothing in art 27 to prevent it. See O. Dörr and K. Schmalenbach (eds), Vienna Convention on the Law of Treaties, (Berlin: SpringerVerlag, 2012), 462.

1261961 Commentary (n 26), 440. 
Illicit Traffic in Dangerous Drugs, ${ }^{127}$ which was interpreted at the time of signature as meaning that the parties have a discretion to take into account 'mitigating circumstances' ${ }^{128}$ If nothing else, this implies that discretion is retained but on a case by case basis and the authors of the 1936 Convention did not conceive of it as permitting a blanket decision not to prosecute based on internal law. The United States authorities do enjoy a broad prosecutorial discretion. ${ }^{129}$ They may also point the Netherlands reliance on expediency as precedent. It is probably untenable to argue that formal guidance as to discretion is always impermissible, but Krajewski's view that this discretion should be applied with circumspection and only to minor offences or it would otherwise undermine the system is more plausible in the light of the history of pressure on States by other states to make the prohibition system effective. ${ }^{130}$ Moreover, it is state law which precedes and which de facto dictates Federal prosecution policy in this case. The United States riposte may be that they it is not exercising its discretion in a blanket fashion but rather it is choosing not to prosecute certain cases due to limited resources made even more limited by the fact that it can no longer rely on state authorities to assist (using the mirror provisions of the CSA contained until recently in state law). The Cole Memorandum explicitly says that if there is a strong federal interest nothing in the policy will prevent prosecution even where none of the priorities are present. ${ }^{131}$ Nonetheless, this decision involves a large number of cases in a specific place in regard to a specific substance, some of which may be regarded as serious using the government's own yardstick of quantity of substance supplied; it is far more than the exercise of discretion in a particular case. Furthermore, the discretion argument ignores the fact that the duty to criminalise supply offences under article 3(1) of the 1988 Convention is subject to article 3(6) which obliges them to endeavour to ensure that any discretionary legal powers are used to maximize the effectiveness of law enforcement and with due regard to the need to deter these offences. The current federal policy cannot be said to be an endeavour to deter the sale of cannabis in Colorado and Washington. The Federal authorities may respond that it has enabled the suppression of trafficking in other drugs through reallocation of resources, but they would be more convincing if they were engaging in selective prosecutions within these States of large scale cannabis supply operations.

It also appears untenable to rely on the broader safeguard clauses such as the provision in article 2(1) of the 1988 Convention that States parties must carry out the obligations in the convention 'in conformity with the fundamental provisions of their respective domestic legislative systems' or the more specific provision in article 36(1) of the 1961 Convention that subjects its criminalisation obligation to the party's 'constitutional limitations' justifies a blanket decision not to prosecute in this way. Safeguard clauses of this kind are not blanket get -outs for non-performance of specific obligations unless the domestic law prevents compliance with the particular obligation. As the Canadian delegate who introduced the provisos in article 36(1)(a) and (b) noted, they were included because 'it was useless to impose on countries obligations which they could not meet without changing their legal system'. ${ }^{132}$ The US federal authorities are not constitutionally or legally prevented from prosecuting the cultivation and

127 Signed at Geneva on 26 June 1936, 198 LNTS 300; in force 26 October 1939.

1281961 Commentary (n 26), at 449, fn 9. It was copied from article 17 of the International Convention for the Suppression of Counterfeiting Currency and Protocol, 20 April 1929, 1931 LNTS 45; 112 LNTS 371.

${ }^{129}$ See Bordenkircher v. Hayes 434 U.S. 357, 364 (1978).

${ }^{130}$ K. Krajewski, 'How Flexible are the UN Drug Conventions?' (1999) 10 International Journal of Drug Policy 329, 336.

${ }^{131}$ Cole Memorandum (n 112), 4.

${ }^{132}$ United Nations Conference for the Adoption of a Single Convention on Narcotic Drugs, Official Records, Volume II (New York, 1964) UN Doc. E/CONF.34/24/Add.1; UN Publication Sales No. 63.XI.4., p. 233. 
supply of cannabis within Colorado and Washington, they are choosing not to do so as a matter of policy.

The Cole Memorandum de facto if not de jure concedes the existence of a jurisdiction within Colorado and Washington to effectively regulate cannabis markets. Together, the state law and the decision not to prosecute if the state law works can arguably be taken to result in non-compliance with provisions in the drug conventions such as article 4 of the 1961 Convention's unqualified duty 'to limit exclusively to medical and scientific purposes the production, manufacture, export, import, distribution of, trade in, use and possession of drugs'. AS noted, it for the State party to ensure that the Convention applies in all of its federated components. The INCB anticipated this controversy when it stated in 2011:

281. The international drug control treaties must be implemented by States parties, including States with federal structures, regardless of their internal legislation, on their entire territory. While all States have different legal systems and legal traditions, the Board wishes to remind the States parties of the basic principles of international law enshrined in the provisions of articles 27 (on the irrelevance of internal law) and 29 (on the application of the treaty on the entire territory of the party) of the 1969 Vienna Convention on the Law of Treaties. ${ }^{133}$

The INCB has not asked the United States to explain what provisions of its constitution or domestic law prevent it from complying, although arguably it may do so. ${ }^{134}$

Whatismore, the non-prosecution of the banking of the proceeds of the cannabis markets in the states where it has been established almost certainly violates the obligation on the United States to criminalise money laundering in article 3(1)(b) and (c) of the 1988 Convention and in article 6 of the UN Convention against Transnational Organised Crime by both enacting an appropriate law (which has been done) and by enforcing that law. ${ }^{135}$

The alternative view is that if these acts continue to be established as a criminal offence in the entirety of US territory the drug convention obligations are met, because the safeguard clauses permit such flexibility and they are being interpreted in this way by States parties in their practice without complaint by others (as yet). The US's taking of this view exposes a contradiction between the US's post-war rhetorical commitment to supply control and its own practice. It appears to be intent on sticking with the existing treaties, fostering flexible interpretation to suit changing conditions, tolerating different national strategies and countering transnational criminal networks. ${ }^{136}$ In 2014 President Obama said:

The U.N. drug conventions, which recognize that the suppression of international drug trafficking demands urgent attention and the highest priority, allow sovereign nations the flexibility to develop and adapt new policies and programs in keeping with their own national circumstances while retaining their focus on achieving the conventions' aim of ensuring the availability of controlled substances for medical and scientific

${ }^{133}$ Report of the International Narcotics Control Board for 2011 (n 58), 38, para 281.

134 See 1961 Records vol. 2 (n 132), 243, where the Legal Advisor notes that the 'organ supervising the execution of the Convention would be entitled to inquire what provisions of their constitution or domestic law prevented them from complying.'

135 The United Nations Convention against Transnational Organized Crime, opened for signature 15 November 2000, 2225 UNTS 209, in force 29 September 2003. The US ratified the Convention on 3 November 2005.

${ }^{136}$ Bennet and Walsh (n 117), 8, citing remarks made by William Brownfield, the Assistant Secretary of State for International Narcotics and Law Enforcement Affairs, at a Debate at the Centre for Strategic and International Studies in 2014. 
purposes, preventing abuse and addiction, and suppressing drug trafficking and related criminal activities. ${ }^{137}$

This leaves the drug control system as a functioning system. Yet there is nothing like a $t u$ quoque accusation to undermine claims by the United States that another State party is breaching its promises. It may be that the US will be accused of undermining the international drug control system by States with growing internal drug use problems of their own who appear to be stronger disciples of the drug war than the originator of this term.

\section{WALTZING, DICORDANCE, OR A NEW TUNE?}

The prohibitionist nature of international drug control has been accepted in an uncontested way since drug control fell under UN auspices. Although practice has not been uniform everywhere, a majority of States parties have opted for an at least rhetorical (if not actual) commitment to a predominantly law enforcement approach. This essentially political approach is not always reflected in the nature of the conventions, in particular the 1961 and 1971 conventions, which do permit a degree of flexibility on specific issues of criminalization. However, the political norms that structure international drug control are the production of continuous human effort within the practice of States. When some States through their practice begin to challenge these objectives of the system, they can destabilise what many assume to be immovable. First in regard to use, and more recently in regard to supply, the practice of some States has moved some distance from the objectives of the strict prohibitive position of limitation of the supply and use of drugs to medical and scientific purposes and elimination of others forms of supply and use. It has occasioned repetitive condemnation in the INCB. ${ }^{138}$ This condemnation has, however, begun to sound increasingly weary because it is the States parties themselves that guard the Vienna consensus, and that consensus is under pressure.

There are credible arguments that the current system does not meet the overall health and welfare purposes of the conventions. So what does the future hold? One cannot be sanguine about making predictions of major reform of the drug control system; there is too much institutional inertia and too many States have bought heavily into the current approach as the only possible way of controlling their domestic drug problems. On the other hand the major proponent of the current system, the United States, which lost control of the opium question to the League in 1920, regained it in 1946, appears now to be loosening its grip, and of being forced by internal pressure into becoming a reluctant proponent of flexible interpretation. Although rhetorically committed to the drug conventions as frameworks for the effort to suppress the international drug traffic, ${ }^{139}$ the US's present ambivalent policy is likely to have an effect on the rigidity of the system as a whole.

One possibility for further change is modification of obligations in respect of certain substances (cannabis is the most likely candidate) amongst like-minded groups of States parties to the conventions, relying on article 41 of the Vienna Convention. ${ }^{140}$ Other States parties more committed to absolute prohibition may object to a proposed variation of this kind on the basis of incompatibility with the object and purpose of the drug conventions. If the variation makes

\footnotetext{
137 'Presidential Determination-Major Drug Transit or Major Illicit Drug Producing Countries for Fiscal Year 2015’, 15 September 2014, cited in Bennet and Wells (n 117), 10.

${ }^{138}$ See Bewley-Taylor, Blickman and Jelsma (n 88), 32-41.

${ }^{139}$ Presidential Determination no. 2014-15 of September 15, 2014, 'Presidential Determination on Major Drug Transit or Major Illicit Drug Producing Countries for Fiscal Year 2015,' 79 Fed. Reg. 56625 (22 September 2014), at 55626.

${ }^{140}$ See Bewley-Taylor, Blickman and Jelsma (n 88), 66.
} 
it past this hurdle the crunch may come if there is an increased flow of controlled substances from the States Parties that have modified their obligations into other States Parties that have not, giving the latter a material basis for objecting that the modification is affecting their enjoyment of their rights under the treaties or adding to their legal and social burdens. The emerging multispeed drug control system would begin to display friction between its different parts. It would be more principled to align the conventions accurately with the actual criminal laws being enforced against individuals, if only out of respect for the principle of legality. Ideally, States should heed the calls for attempted reform of the system as a whole ${ }^{141}$ and regenerate consensus in Vienna, but of a different kind.

${ }^{141}$ See, for example, Bennet and Walsh (n 117), 3. 